\title{
Infant Formula Trade and Food Safety
}

\author{
Sarah W. Adelman ${ }^{1} \&$ Katherine N. Schmeiser ${ }^{1}$ \\ ${ }^{1}$ Mount Holyoke College, 50 College Street, South Hadley MA 01075, USA \\ Correspondence: Katherine N. Schmeiser, Mount Holyoke College, 50 College Street, South Hadley MA 01075, USA.
}

Received: October 7, 2018

doi:10.11114/aef.v6i1.3754

\author{
Accepted: October 29, $2018 \quad$ Available online: November 7, 2018 \\ URL: https://doi.org/10.11114/aef.v6i1.3754
}

\begin{abstract}
Beginning in 2004, the Chinese formula market suffered from a string of contamination events from counterfeit formula in 2004, melamine in 2008 to mercury and aflatoxin (a human carcinogen) in 2012. In this paper, we seek to understand the effects of these safety concerns in a market which lacks product substitutes. Whereas the literature shows international flows for produce, beef, and poultry are changed by persistent contaminations, the international infant formula market is less responsive to repeated health concerns.
\end{abstract}

Keywords: trade, gravity, infant health, food safety

\section{Introduction}

Infant formula, a $\$ 41$ billion market, is the only nutritionally acceptable alternative to human breast milk. Contaminated or misused infant formula can lead to extreme malnutrition, illness or death. In a high profile case in 2008, six infants in China died due to melamine-contaminated infant formula (this followed a previous - more deadly contamination in 2004). Contamination concerns arose again in 2010 and 2012, and news sources reported that domestic demand for Chinese-produced infant formula fell drastically as a result of these formula scares, driving up demand for formula imports. Infant formula is a product that is necessary for babies who do not or are unable to receive breast milk. It lacks safe marketed substitutes (another, less recommended option is goats milk). In this paper we show that while formula imports to China have increased drastically, despite the media outcry, the health scares may not be the main drivers. Additionally, we do not find a persistent decline in China's exports -consistent with findings following a contamination scare in New Zealand in 2013. These findings however are inconsistent with outcomes of other food safety incidents, such as produce, beef and poultry, in which persistent contaminations lead to export market collapse. We speculate on why the formula market behaved differently than other food markets.

Food safety scares are a common occurrence around the world. In the United States in 2017, the FDA recorded 456 food recalls, which can be voluntarily initiated by the manufacturer or distributor, or initiated by the FDA. Recalls can take time, as tracing the origin of a contamination through the manufacturing process is difficult, even in the US. When a recall of a foreign product is made, imports of the product may temporarily stop (this may be for the duration of, for example, a single growing season). In China, food safety is monitored by the The Food Safety Commission Office (FSCO). A 2014 survey conducted by Horizon Research and Horizonkey in Beijing found that 80 percent of the 3,166 respondents were not satisfied with food safety in China. 60 percent of respondents believed food companies have performed poorly in food. (Dan \& Hongyi, 2014)

Infant formula is a critical market to evaluate both because of its significance to infant nutrition and development and because of its lack of marketed substitutes. The World Health Organization (WHO) recommends exclusive breastfeeding for the first six months of an infant's life, followed by breastfeeding with complementary feeding for up to 2 years. However, globally only $38 \%$ of infants are exclusively breastfed for the first 6 months, and all infants require the nutrition of breast milk or formula until at least 1, leading to a significant demand for infant formula. Because it is crucial to the health and development of children, the infant formula market - both in production and marketing, is highly regulated to ensure safe nutritional values. However, the marketing of infant formula has been controversial for many years. McFadden et al. (2016) argue that active and aggressive promotion by manufacturers and distributers shows inadequate implementation and enforcement of the WHO code and is a substantial global barrier to breastfeeding. They argue that further international collaboration should be used to monitor and enforce the code. Anttila-Hughes et al. (2018) show that with controversial marketing (providing samples to mothers), when mothers don't have access to clean water, availability of formula increases infant mortality. 
Infant formula trade flourished in the 1960s following the U.S. baby boom as producers turned towards international markets to expand their consumer base (Sethi, 1979). The Global Health community expressed significant concerns that the increasing availability of infant formula would displace breastfeeding, along with concerns about the safety of traded infant formula. To promote breastfeeding and combat the global trend towards formula feeding, the WHO developed the International Code of Marketing of Breast-milk Substitutes, which includes prohibiting advertising directly to the public, free samples, and promotion of products in health care facilities (such as hospitals sending mothers home with sample products). However, 30 years after introduction of the code, only $19 \%$ of countries have passed laws supporting the entire code. $35 \%$ prohibit advertising, $31 \%$ prohibit free or low cost samples, $32 \%$ prohibit gifts to health workers and $42 \%$ require a message about superiority of breastfeeding on the label. (WHO 2013 revised) As recently as July 2018, the United States -- contrary to 40 years of scientific research and to the surprise of much of the world, opposed a resolution to encourage world wide breastfeeding. (Jacobs, 2018)

We first describe the contaminations in Chinese infant formula before reviewing the literature on other food contamination cases and the effects on world trade. We then look at how persistent safety issues in Chinese formula affect trade both over time and across regions. We find, surprisingly, that China's exports do not suffer from persistent safety issues. These results may be for a variety of reasons we do not investigate in this paper: with few product substitutes, consumers may not have access to alternate suppliers in their countries; good information may be costly for consumers to obtain (about the origin of formula, potential safety and quality issues); or government monitoring (or trust in it) may be high. Most importantly in this case, China is not a significant exporter of formula anywhere in the world (the formula industry is dominated by just a handful of companies). Additionally, while imports of formula in China grow drastically, much of the formula imports in response to the contaminations seem to have been done through non-marketed channels, as we discuss later, making these trends hard to capture.

\section{Chinese Infant Formula}

Food fraud is illegal deception for economic gain using food. Adulteration is when there are ingredient substitutions, dilution, concealments, or impurities. Food fraud can lead to public health threats and be devastating economically to countries due to lost consumer confidence. (Moyer, DeVries \& Spink, 2017)

Reports of substandard formula in Fuyang, China lasted for almost a year without significant government action. In Anhui Province officials did not remove the counterfeit formula until April of 2004. Fuyang is located in a poor part of China and the babies that consumed the counterfeit low-cost formula (a problem which was concentrated in Fuyang) developed swollen heads ("big head disease") and 13 babies died and nearly 200 others fell sick. A government spot check in stores in Guangdong Province found 33 percent of formula brands did not meet national standards, with some in Fuyang testing at less than 1 percent protein (with the national standard being 12 percent). (Yardley, 2004)

In 2008, six infants in China died from consuming contaminated infant formula. In order to increase the volume of production, water had been added to raw milk resulting in a lower protein concentration. Melamine was then added to increase the nitrogen content of the milk and its apparent protein content. More than 290,000 people were poisoned with 54,000 infants sick or hospitalized due to kidney complications (Xiu \& Klein, 2010). Two people received death sentences in Chinese courts with five others receiving life sentences. Countries around the world temporarily imposed bans on imports of Chinese goods that contained milk ingredients, and a new food safety law was implemented on June 1, 2009. (Xiu \& Klein, 2010).

Even with new laws and attempts to control safety of exported food through certifying farmers and exporters, monitoring remained challenging for Chinese authorities (Buzby \& Gale, 2009) and tainted formula did not end with the 2008 contamination. In 2010, 76 tons of dairy ingredients that somehow were not removed from the market in the 2008 recall were discovered in the Qinghai Province (Wines, 2010). In 2012, some batches of infant formula were found to contain dangerous levels of mercury and then, just a month later, formula was found with excessive levels of aflatoxin, a cancer-causing toxin that is produced by mold or fungus. (McDonald, 2012) While the government's response to the contaminations was swift and severe, certainly by 2012 persistent problems led to poor perceptions of Chinese formula quality.

Chinese consumption accounted for $23 \%$ of the $\$ 41$ billion global market for baby food and formula in 2013 . With domestic formula safety concerns, Chinese consumers were reported to go on "formula runs" to other parts of the world, leading to formula rationing in Australia and parts of Europe. (Siegel, 2013) Chinese customs authorities began enforcing strict limits on how much formula Chinese nationals could carry back into the country. (Wong, 2013) Online sales rose from $2 \%$ of Chinese infant formula sales in 2010 to $22 \%$ in 2015. Imports of baby formula made entirely outside of China, for a company such as Mead Johnson, rose from 5\% in 2014 to 35\% in 2015. Another response to the safety concerns is the increased rate of breastfeeding newborns- 6 months old, which rose from $28 \%$ in 2008 to $59 \%$ in 2016. (Craymer, 2016). 
One barrier to consumers is that, despite strong marketing codes internationally, information on the health and safety of formula products is hard to gather. For example, Nestlé (the global leader in infant milk products, with market share of around a quarter) was accused of violating the marketing codes and providing misleading nutritional claims about infant formula. For example, it marketed formula in Hong Kong as being free of sucrose for baby's health even while using sucrose in formula in other parts of the world. Formula was promoted as being healthier because it was free from vanilla flavorings in Hong Kong, while selling vanilla flavored formula nearby. (Nelson, 2018)

The international market is not unfamiliar with food (or pharmaceutical) contaminations however, infant formula does not have marketed substitutes. Although consumers can switch producers of infant formula (say from domestic formula to imported formula, or formula imported from China to formula imported from another country), alternative products are not always readily available or affordable. Below, we discuss the literature on food safety contaminations in the produce, beef, and poultry markets and the subsequent results for the international market. We then look at the international formula market to see what occurs when there are recurrent safety concerns in Chinese produced formula.

\section{International Trade and Food Borne Illnesses}

In 2003, the USDA produced a study on international trade and food safety (Buzby, 2003). They found that overall there is relatively little disruption to international trade due to safety concerns because of the market size and changes in production and consumption over time. Buzby and Unnevehr (Chapter 1, 2003) find that for the United States, there is no evidence that food safety risks are correlated with trade volume - primarily because there are many alternative exporters and producers that provide flexibility in the global market. Additionally, consumers regain trust in the food supply with announcements of safety oversights and the passage of time.

In this section we review three types of outbreaks that have previously been studied: contaminated produce, Mad Cow Disease (Bovine Spongiform Encephalopathy (BSE)), and Avian Flu (highly pathogenic avian influenza (HPAI) virus, type H5N1). We follow this with a review of a false contamination report of dairy products originating from New Zealand.

Produce: Calvin (2004) finds that the effects of an outbreak of food borne illness can be far-reaching. For example in the summer of 1996, California strawberries were mistakenly blamed for what was actually a Guatemalan raspberry outbreak of cyclospora, costing the industry $\$ 16$ million. (Mishen, 1996) Since produce growing seasons are short, by the time the product and origin of an outbreak are identified, the harvest cycle of the contaminated crop might be over. Exporters of the contaminated goods may not suffer during the actual outbreak, but consumers then become overly cautious about similar products, regardless of their origin, leading to problems for domestic producers or exporters with later growing seasons.

The produce market also shows that export markets recover quickly unless there are repeated concerns about food safety. For example, after the source of the cyclospora outbreak was traced to Guatemalan raspberries, Guatemala suffered a second consecutive outbreak. Despite putting in place an improved food safety system, the industry never recovered. On the other hand, after Mexican strawberries were implicated in a separate outbreak, initial exports plummeted but rebounded in following years because there were no repeat outbreaks. So while exporters appear to recover from single food safety incidents, persistent outbreaks from a region can decimate a particular export market.

Beef: In 1996, the linkage was made between mad cow disease (BSE), found in UK cattle, and its deadly human variant, Creutzfeld-Jakob Disease (vCJD). Three major mad cow crises in the UK decimated its export industry as many countries imposed bans on imports from the UK (Mathews, Bernstein \& Buzby, 2003). Pickelsimer and Wahl (2002) show that UK exports dropped from 77,000 metric tons of beef in 1995 to less than 2,000 metric tons in 2000. Other EU exporters were also affected to a lesser extent: France's exports dropped from 154,000 to 55,000 metric tons over the same period, and Germany's exports went from 212,000 to 130,000 metric tons. Domestic beef consumption throughout Europe declined as consumers substituted toward lamb, pork, poultry and cheese. However, the world beef market did not take a drastic hit to supply as countries like the United States, Canada, Brazil, New Zealand and Australia replaced affected exporters. Demand outside Europe did not fall either. Subsequently EU exporters outside the UK have recovered and domestic beef consumption returned to its long-term trend (Mathews, Bernstein \& Buzby, 2003).

Pickelsimer and Wahl (2002) do show important regional distribution changes: developing countries - without the same strict safety standards and income -- were less protected from tainted imports. While Britain banned use of mammalian feed in the domestic food chain, they still exported the tainted feed to the developing world.

Poultry: Nicita (2008) studies Avian Influenza and has similar findings to the beef and produce markets -avian flu had little impact on the worldwide volume of trade but it did change international flows. As Avian flu is a persistent concern, importing countries responded to the outbreak by banning imports from afflicted countries or regions (some switched to regional trade bans within countries as the outbreaks often were more isolated). China and Thailand's exports of poultry meat plummeted due to the outbreak, with Brazil taking the place as the world's largest supplier of raw poultry products. 
In the produce, beef and poultry markets, persistent outbreaks shut down regional markets, restructuring international trade flows to allow safe producers to take their place. Exporters experiencing only one outbreak and implementing reforms tend to recover quickly. The infant formula market is different from those analyzed above. There are no product substitutes and there is huge worldwide demand - particularly from middle income countries. Before we analyze how the contaminations affect Chinese exports and imports of infant formula, we review a case of contamination in New Zealand formula.

Formula: Walters (2013) discusses how the Fonterra botulism scare affected New Zealand infant formula exporters. Fonterra is a multinational dairy cooperative located in New Zealand - the largest milk exporter in the world. In August of 2013, there was a product recall which affected 20 countries. This voluntary recall was based on incorrect information leading to the belief that Fonterra's dairy products were tainted with botulism. Specifically they were concerned that three batches of their whey protein concentrate (commonly used in infant forumla) had been contaminated with Clostridium Botulinum. Within 25 days, further testing allowed the company to confirm the alarm was false. (Stojkov, Noy, \& Saglam, 2018) 30 New Zealand companies were directly affected by this recall and it was estimated that companies would loose $\$ 2$ million a year based on lost confidence from domestic and Asian markets. Walters also discusses how companies not affected by the recall itself suffered from lost sales based on the perception of tainted product from New Zealand. Hussain and Dawson (2013) discuss how this short term disruption causes severe impact on small food companies based in New Zealand.

Stojkov et al. (2018) analyze the effects of this (false) recall on New Zealand dairy exports which led to Sri Lanka, Russia and China imposing complete bans on some New Zealand Dairy products (although China, for example, removed it's ban 2 months later). Their analysis shows that the incident had no long term significant impact on the total value of most dairy exports which is consistent with the non-persistent nature of the other markets analyzed above. However, they do find that for whey products and infant formula, there is a statistically significant and persistent negative impact on exports. The authors conclude, however, that because there was actually an initial short-term recovery of infant formula exports, and because other dairy products did not suffer long term negative impacts, that the impact on formula exports was not caused by fears of New Zealand dairy products. We now turn to analyzing the case of Chinese contaminations. Whereas New Zealand is the world's largest exporter of dairy, exporting $51 \%$ of whole milk powder, (Stojkov et al., 2018) China is a very small exporter. For New Zealand's dairy exports, there is no clear connection between the (perceived) one time contamination and reduced exports. China's contaminations were repeated and real. We begin by discussing the data below.

\section{Data}

Consumption of formula is not available, nor is sales of domestically produced formula. Our best approximate for formula data is trade data (in current USD) from the United Nations Comtrade (UN Comtrade, 2018) harmonized system code 190110 infant foods of cereals, flour, starch or milk for retail sale. We use all potential trading pairs with China for the years 2000-2016. Weighted distance in between potential trading partners come from the CEPII gravity database (CEPII 2014) and GDP (current USD) is taken from the World Development Indicators (World Bank, 2016). We use the US GDP deflator from FRED, base year 2009. When comparing to total trade, we use SITC total trade or product categories 6-8 for manufacturing trade (UN Comtrade, 2018).

Table 1. Descriptive Statistics

\begin{tabular}{ll}
\hline & Global \\
\hline GDP (Millions), (USD 2009) & $2,915,243.77$ \\
& $(1,267,453.50)$ \\
Formula Trade, USD 2009 & $3,275,667,147.29$ \\
Formula Trade, kg & $(1,958,329,416.52)$ \\
& $581,893,867.29$ \\
& $(253,076,689.21)$ \\
\hline GDP (Millions), (USD 2009) & China (yearly averages) \\
& $5,333,484$ \\
Formula Exports, USD 2009 & $(2,400,437)$ \\
& $3,466,450$ \\
Formula Imports, USD 2009 & $(6,907,014)$ \\
& $722,154,969$ \\
Formula Exports, kg & $(817,880,363)$ \\
& 505,952 \\
Formula Imports, kg & $(547,041)$ \\
& $65,770,711$ \\
Proportion of global formula trade & $(64,448,373)$ \\
$N$ & .0007149 \\
\hline
\end{tabular}

Notes: Standard deviations in parentheses for means. 
Average global formula trade in a given year averages approximately $\$ 3$ billion (USD 2009) during our sample period. China on average imports $\$ 722$ million dollars of formula, and exports only $\$ 3.5$ million dollars worth. China's exports increased over this period by $1600 \%$ while their imports increased by $5900 \%$ (and in weight, by $150 \%$ for exports and $3100 \%$ for imports).

Although China's exports (in value, weight, and as a proportion of world exports) increased drastically over this period, as a proportion of total formula exports China remains a small exporter, exporting only $0.1 \%$ of world formula exports in 2000 and $0.3 \%$ 2016. As an importer however, China consumed on averaged about $13.6 \%$ of world formula exports ever increasing over the 2000-2016 period. In 2000 China imported under $4 \%$ of traded world formula, ending at over $33 \%$ in 2016.

Figure 1 looks at China's formula exports in contrast to their overall manufacturing exports over the period 2000-2016. The solid line shows that formula exports increased dramatically over time. With the 2012 alfatoxin scare, there is an initial suggestion of trade disruption, but even after 3 health concerns in under 5 years, 2013 export values are still higher in value than at any point before 2008, and exports after 2014 clearly increase drastically. As Chinese exports were also growing this time, we also show manufacturing exports with the dashed line which also increases substantially over this period.

With respect to China's formula imports, Figure 2 shows that formula imports are increasing in value (solid line). This increase may reflect changing demand for imported formula among Chinese consumers who are more acutely aware of the health concerns with domestically-produced formula, or could be due to economic growth, for example. The dashed line shows corresponding manufacturing imports over this time period and in fact, all regression analyses show that imports of formula are not growing more than manufacturing in a significant way, despite the health scares.

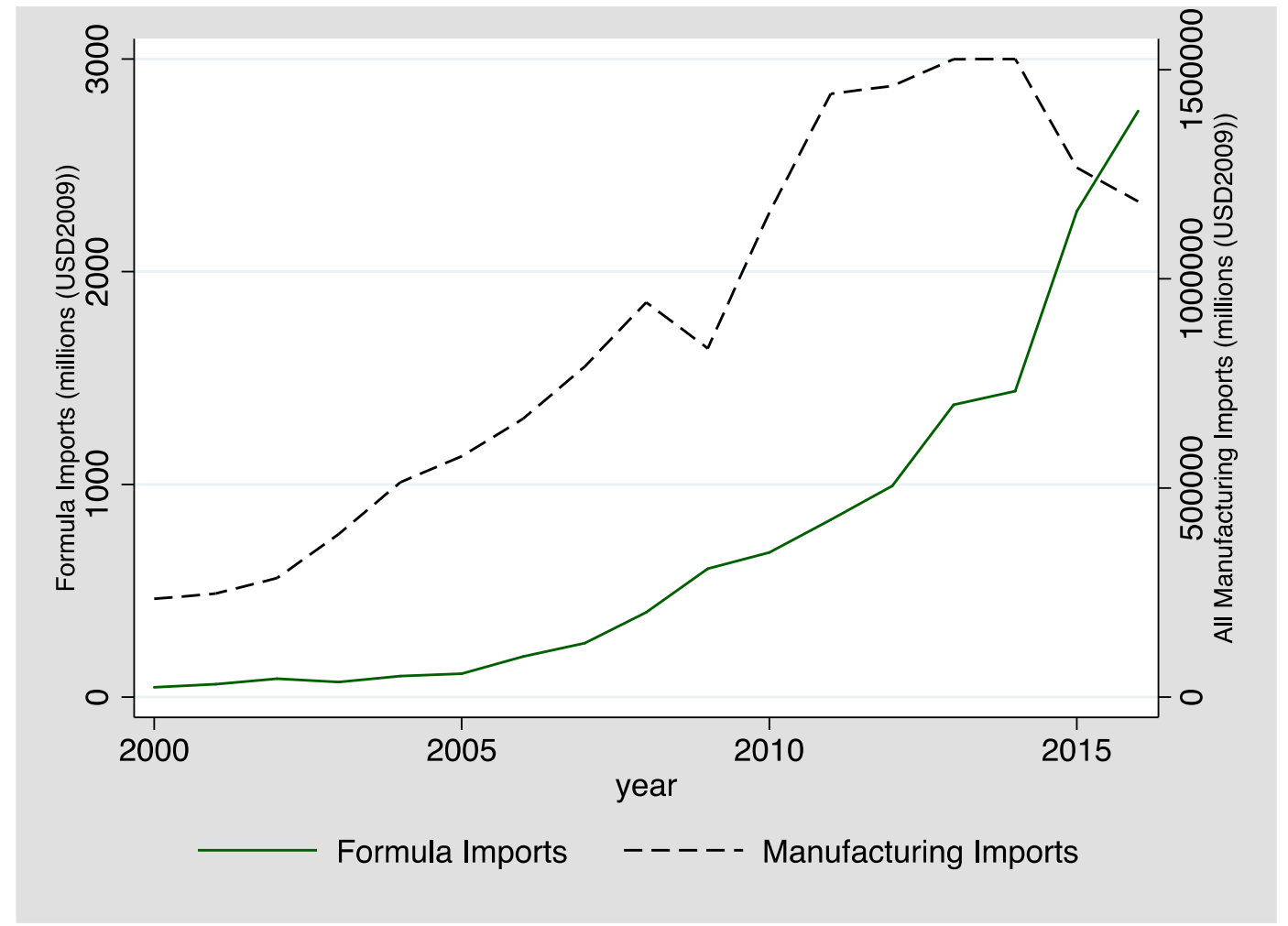

Figure 1. Chinese Exports 


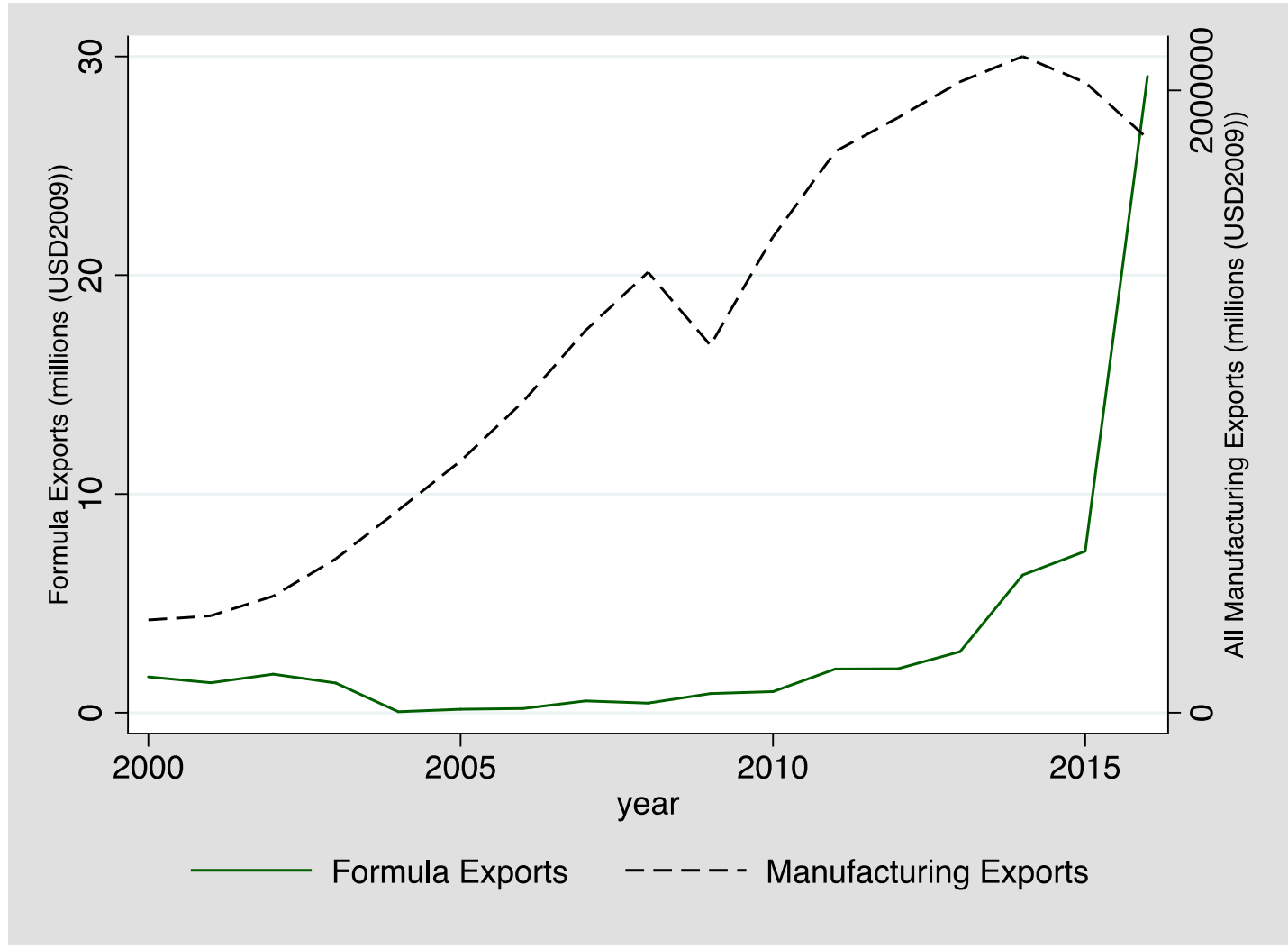

Figure 2. Chinese Imports

Graphically we see that while there may have been small disruptions following the main contaminations, it's not clear without further econometric analysis whether China's formula trade market was significantly affected. Most movement as we know anecdotally may have occurred in imports not captured by customs. In the next section, we show there is no long-term negative impact of the multiple health scares on Chinese exporters as predicted by the literature, nor do imports change in a drastic way. Additionally we look at regional changes in trade partners with China.

\section{Results}

Sun, Huang and Yang (2014) use a gravity model to show that increasing safety standards in China do not affect total dairy imports. The reason for this is that the safety standards within China tend to be lower than the standards of the developed countries they import from. They also show that dairy imports have increased over time as population has increased and tariffs decreased. They do, however find that the melamine scare in 2008 led to a positive and statistically significant increase in total dairy imports due to domestic safety concerns. We perform a similar analysis to Sun et al.

Our econometric analysis shows that after controlling for the size of the relevant economies, there are no statistically significant changes in Chinese imports following the formula health scares. In column 1 we show results from a model regressing logged imports on exporter GDP (USD 2009), China's GDP, distance between China and the exporter, and a dummy variable for year 2008 to indicate the highly publicized (internationally and domestically) melamine scare. Column 2 and 3 include dummies for longer time periods to pick up persistent changes in behavior following a scare. Column 3 also includes interactions of these time period indicators with China's GDP to see if the size of China's economy continues to be the major driving force in import demand following domestic formula safety scares. All estimates show the predicted results for the gravity variables, however, after controlling for these variables we see no short or persistent increases in demand for imported formula. Demand changes are consistent with China's economic growth during the period. 
Table 2. China's Formula Imports (Total value, USD 2009), 2000-2016

\begin{tabular}{|c|c|c|c|}
\hline & $(1)$ & $(2)$ & (3) \\
\hline $\ln$ (GDP, exporter) & $\begin{array}{l}0.426 * * * \\
(4.36)\end{array}$ & $\begin{array}{l}0.427 * * * \\
(435)\end{array}$ & $\begin{array}{l}0.427 * * * \\
(4.34)\end{array}$ \\
\hline $\ln (\mathrm{GDP}, \mathrm{China})$ & $0.987 * * *$ & $1.260 * * *$ & 0.313 \\
\hline & $(11.14)$ & $(3.73)$ & $(0.40)$ \\
\hline $\ln ($ Distance $)$ & $-0.983 * *$ & $-0.981 * *$ & $-0.981 * *$ \\
\hline & $(2.00)$ & (1.99) & $(1.99)$ \\
\hline Year 2008 & $\begin{array}{l}-0.280 * \\
(1.79)\end{array}$ & & \\
\hline Years 2004-2007 & & $\begin{array}{l}-0.603 * * * \\
(3.48)\end{array}$ & $\begin{array}{l}-8.103 \\
(0.30)\end{array}$ \\
\hline Years 2008-2011 & & $\begin{array}{c}0.014 \\
(0.08)\end{array}$ & $\begin{array}{c}-30.161 \\
(1.14)\end{array}$ \\
\hline Years 2012-2016 & & $\begin{array}{c}0.173 \\
(1.10)\end{array}$ & $\begin{array}{c}-32.587 \\
(1.11)\end{array}$ \\
\hline $\ln (\mathrm{GDP}, \mathrm{China})^{*}$ Years 2004-2007 & & & $\begin{array}{l}0.272 \\
(0.29)\end{array}$ \\
\hline $\ln (\mathrm{GDP}, \mathrm{China})^{*}$ Years 2008-2011 & & & $\begin{array}{l}1.036 \\
(1.14)\end{array}$ \\
\hline $\ln (\text { GDP, China })^{*}$ Years 2012-2016 & & & $\begin{array}{l}1.097 \\
(1.10)\end{array}$ \\
\hline Constant & $\begin{array}{l}-28.660 * * * \\
(5.40)\end{array}$ & $\begin{array}{l}-36.302 * * * \\
(3.39)\end{array}$ & $\begin{array}{l}-9.221 \\
(0.41)\end{array}$ \\
\hline$N$ & 3,110 & 3,110 & 3,110 \\
\hline
\end{tabular}

$* p<0.1 ; * * p<0.05 ; * * * p<0.01$

All models are estimated with exporter random effects. Including exporter fixed effects has virtually no impact on the point estimates or standard errors, however fixed effects prevent estimation of the coefficient on logged distance from the trading partner.

We repeated the exercise above for China's formula exports (Table 3) and find that exports are not affected by the safety scares. If anything, exports to higher income countries appear to be increasing over the last 6 years of our analysis. Note that our results vary from Sun et al (2014) due to data differences (they use total dairy trade and we restrict to products marketed for infants) and the fact that the formula runs were likely not captured in the data.

Table 3. Exports from China (\$2009US), 2000-2016

\begin{tabular}{|c|c|c|c|}
\hline & $(1)$ & $(2)$ & $(3)$ \\
\hline \multirow[t]{2}{*}{$\ln (\mathrm{GDP}, \mathrm{China})$} & $0.113 *$ & 0.129 & 0.130 \\
\hline & $(1.95)$ & $(0.54)$ & $(0.55)$ \\
\hline \multirow[t]{2}{*}{$\ln (\mathrm{GDP}$, importer) } & $0.093 * * *$ & $0.093 * * *$ & $0.072 *$ \\
\hline & $(2.86)$ & $(2.85)$ & $(1.88)$ \\
\hline \multirow[t]{2}{*}{$\ln ($ Distance $)$} & $-0.806 * * *$ & $-0.806 * * *$ & $-0.804 * * *$ \\
\hline & $(5.23)$ & $(5.21)$ & $(5.16)$ \\
\hline \multirow[t]{2}{*}{ Year 2008} & 0.083 & & \\
\hline & $(0.75)$ & & \\
\hline Years 2004-2007 & & $\begin{array}{l}-0.090 \\
(0.73)\end{array}$ & $(0.49)$ \\
\hline \multirow[t]{2}{*}{ Years 2008-2011 } & & -0.099 & 0.246 \\
\hline & & $(0.79)$ & $(0.32)$ \\
\hline \multirow[t]{2}{*}{ Years 2012-2016 } & & $0.189 *$ & $-3.388 * * *$ \\
\hline & & $(1.69)$ & $(4.70)$ \\
\hline \multirow[t]{2}{*}{$\ln ($ GDP, importer)* Years 2004-2007 } & & & -0.019 \\
\hline & & & $(0.61)$ \\
\hline \multirow[t]{2}{*}{$\ln ($ GDP, importer $) *$ Years 2008-2011 } & & & -0.014 \\
\hline & & & $(0.45)$ \\
\hline $\ln ($ GDP, importer $) *$ Years 2012-2016 & & & $\begin{array}{l}0.148 * * * \\
(5.02)\end{array}$ \\
\hline \multirow[t]{2}{*}{ Constant } & 2.067 & 1.651 & 2.110 \\
\hline & $(0.92)$ & $(0.24)$ & $(0.30)$ \\
\hline$N$ & 3,110 & 3,110 & 3,110 \\
\hline
\end{tabular}

$* p<0.1 ; * * p<0.05 ; * * * p<0.01$

The literature for other food markets shows that persistent safety recalls negatively affected country exports. While an initial safety issue did not permanently disrupt a country's market, multiple recalls shut down export markets and supply provided by alternative exporters. The analysis above shows that worldwide trade patterns are not significantly altered by China's health scares. The literature also shows that poorer importers are less responsive to concerns about food safety 
due to less stringent import laws and lack of flexibility in ability to pay (Pickelsimer \& Wahl 2002). Below, we analyze the distribution of countries that both export to and import from China.

Table 4 shows the top ten export destinations of Chinese formula in the years 2000 and 2016. China does not hold a significant portion of any destination. Although the countries that appear do change over our time period, we don't get much information because exports are so small and so few countries receive the products. The destinations are highly concentrated with the top destination in both years receiving approximately $80 \%$ of Chinese exports. It is good, however, to see that large quantities of formula are not suddenly being sent to disadvantaged locations. A gravity analysis also does not support much change though, driven by Hong Kong, it appears that exports remain closer to China.

Table 4. Chinese Exports, Ranked by Destination

\begin{tabular}{|c|c|c|c|c|c|c|c|}
\hline \multirow[b]{2}{*}{ Rank } & \multirow[b]{2}{*}{ Destination } & \multicolumn{3}{|l|}{ Exports 2000} & \multirow[b]{2}{*}{ Importers } & \multicolumn{2}{|l|}{ Exports 2016} \\
\hline & & (millions USD) & Cumulative \% & Rank & & (millions USD) & Cumulative $\%$ \\
\hline 1 & Iraq & 1.333757 & 0.811 & 1 & Hong Kong & 22.80 & 0.78 \\
\hline 2 & Hong Kong & 0.258763 & 0.969 & 2 & Germany & 2.46 & 0.87 \\
\hline 3 & Singapore & 0.020414 & 0.981 & 3 & Macao & 2.24 & 0.94 \\
\hline 4 & Japan & 0.020248 & 0.993 & 4 & Pakistan & 0.79 & 0.97 \\
\hline 5 & Korea & 0.006155 & 0.997 & 5 & New Zealand & 0.27 & 0.98 \\
\hline 6 & Australia & 0.003957 & 0.999 & 6 & Denmark & 0.23 & 0.99 \\
\hline 7 & Myanmar & 0.000589 & 1.000 & 7 & Netherlands & 0.14 & 0.99 \\
\hline 8 & Germany & 0.000299 & 1.000 & 8 & Syria & 0.12 & 1.00 \\
\hline \multirow[t]{2}{*}{9} & Jordan & 0.000005 & 1.000 & 9 & Australia & 0.02 & 1.00 \\
\hline & & & & 10 & Korea & 0.02 & 1.00 \\
\hline
\end{tabular}

Table 5 shows China's imports of formula, ranking origin country in 2000 and 2016. Similar to the export table, we see that the composition of top exporters to China does not change much though clearly the value of imports rose drastically at all ranks. One marked difference is that the countries exporting to China in 2000 were highly concentrated: $70 \%$ of all imports came from Ireland and the next 20\% from the US. By 2016 the market was less concentrated with the top exporter to China (the Netherlands) providing only $33 \%$ of Chinese imported formula. Contrary to Chinese export destinations, imports come from high income countries.

Table 5. Chinese Imports, Ranked by Origin

\begin{tabular}{llllllll}
\hline Rank & Origin & $\begin{array}{l}\text { Imports 2000 } \\
\text { (millions USD) }\end{array}$ & Cumulative \% & Rank & Exporters & $\begin{array}{l}\text { Imports 2016 } \\
\text { (millions } \\
\text { USD) }\end{array}$ & Cumulative \% \\
\hline 1 & Ireland & 32.10 & 0.70 & 1 & Netherlands & 918 & 0.33 \\
2 & USA & 9.10 & 0.90 & 2 & Ireland & 507 & 0.52 \\
3 & Netherlands & 1.87 & 0.94 & 3 & New Zealand & 302 & 0.63 \\
4 & Australia & 1.07 & 0.96 & 4 & Germany & 301 & 0.74 \\
5 & Korea & 0.70 & 0.98 & 5 & Australia & 149 & 0.79 \\
6 & New Zealand & 0.34 & 0.98 & 6 & Denmark & 130 & 0.84 \\
7 & Denmark & 0.28 & 0.99 & 7 & France & 120 & 0.88 \\
8 & Malaysia & 0.27 & 1.00 & 8 & Korea & 89.6 & 0.92 \\
9 & France & 0.06 & 1.00 & 9 & Switzerland & 62.5 & 0.94 \\
10 & Belgium & 0.01 & 1.00 & 10 & USA & 61.3 & 0.96 \\
\hline
\end{tabular}

In summary, we see that while exports and imports increased over the 2000-2016 period, there seems to be no marked affect from the contaminations themselves either in value or composition of trading partners - which seems contrary to the anecdotal evidence from news sources but similar to the results of Stojkov et. al (2018) for the New Zealand dairy market. While this may be because we don't have monthly data, we also know most immediate reactions to the formula scares were in the form of 'formula runs' where travelers carried formula or formula was shipped to friends and family in China. While anecdotal evidence shows us this involved large quantities of formula, it would not be traced in customs data.

\section{Conclusion}

A few interesting patterns emerge when looking at previous case studies on food contamination and international trade flows. For produce, a single outbreak may temporarily disrupt exports but safety improvements and short growing seasons led to no persistent effects for a country's exports. Repeated contaminations however, for produce, beef, and poultry completely eradicate a country's export market with little disruption to world wide trade as different exporters stepped in. 
The infant formula industry is regulated to maintain high nutritional and safety standards and to be advertised in accordance to WHO regulations. With almost two thirds of infants globally relying on formula, a significant change in quality, price or quantity can have enormous repercussions. We suggest that due to the particular nature of infant formula, the contaminations of Chinese infant formula between the years 2004 and 2012 did not collapse the Chinese export market (either regionally or as a whole). In fact, after short disruptions the export market shows growth. It is likely this is due to the very low quantity of product exported from China as well as lack of monthly or imprecise data.

Chinese consumers suffered from the contamination even in addition to the health consequences of tainted formula, with perceived 'safe' formula shortages leading to runs on infant formula as far as Europe and Australia. This means there are likely distributional effects within the domestic market which have larger costs to poorer families less able to pay for imported formula or travel to purchase formula. While imports of formula have increased drastically since 2000, it is unclear that this is driven primarily by the contaminations. In fact, aligned with the news, much of the reactionary imports were done through channels not tracked in customs: the runs on formula in Europe and Australia were done by travelers and family members shipping formula back to China, and so would not appear in our data. The Chinese government did provide swift and severe punishments to perpetrators, so while Chinese consumers may have lacked confidence in domestic formula, there may have been few options available on the shelf. China is currently overhauling it's laws on infant formula in China in an attempt to help domestic producers gain market share. Now, all infant formula sold in China must be registered with the China Food and Drug Administration (CFDA). A company can register no more than nine formulas across 3 product series, and subsidiaries must have necessary technology, equipment, and facilities. Under the new laws, $28 \%$ of registered companies are foreign. Only $40 \%$ of registered companies are purely domestic while $60 \%$ have a foreign investment element. (Bing, King \& Wood Mallesons 2018)

The lack of long term trade response to the repeated formula events (or to the New Zealand 'false' contamination) provides an important lesson to help us understand safety concerns in other industries which have few substitutes, for which information is hard to gather, and where distributional effects are particularly concerning. A recent example would be unsafe vaccines sold throughout China. An investigation was triggered due to fabricated production records of rabies vaccines. Only weeks later, it was found that over 250,000 doses of a vaccine used to protect against diphtheria, pertussis and tetanus -- required for children in China, failed to meet the required safety standars. These vaccines had been sold primarily to the government. The pharmaceutical industry in China has been made a national priority for growth but there have been three vaccine crises since 2010 and in July 2018 the US recalled blood pressure medication that was sold in China. (Hernández, July 23 2018) In addition to the immediate consequences, repeated crises may cause consumers to turn away from vaccines altogether. From the case of infant formula contaminations in China, we can see the importance of government oversight (nationally and internationally) on these types of goods.

\section{References}

Anttila-Hughes, J., Fernald, L., Gertler, P., Krause, P., \& Wydick., B. (March 2018). Mortality from Nestlé's Marketing of Infant Formula in Low and Middle-Income Countries. NBER Working Paper, 24452

Buzby, J. (November 2003). International Trade and Food Safety: Economic Theory and Case Studies. USDA Electronic Report from the Economic Research Service, Agricultural Economic Report, 828.

Buzby, J., \& Gale, F. (July 2009). Imports from China and Food Safety Issues. USDA Economic Information Bulletin, 52.

Buzby, J., \& Unnevehr, L. (November 2003). Chapter 1: Introduction and Overview. USDA Electronic Report from the Economic Research Service, Agricultural Economic Report, 828.

Calvin, L. (February 2004 ). Response to U.S. Foodborne Illness Outbreaks Associated With Imported Produce. Issues in Diet, Safety, and Health, Agriculture Information Bulletin, 789(5).

CEPII. (2014). Retrieved February 2014, from www.cepii.fr

Craymer, L. (2016, August 02). Chinese Head to the Web to Buy Imported Baby Formula; Value of foreign-made infant formula rose $25 \%$ in the first half. Wall Street Journal, 2.

https://www.wsj.com/articles/chinese-head-to-the-web-to-feed-infants-1470157625

Dan, H., \& Hongyi, W. (2014, July 25). Dissatisfaction with food safety pervasive, survey finds. China Daily http://www.chinadaily.com.cn/china/2014-07/25/content_17920201.htm

FRED. Gross Domestic Product: Implicit Price Deflator (GDPDEF). Retrieved July 2018, from https://fred.stlouisfed.org/

Hernández, J. (July 23, 2018). In China, Vaccine Scandal Infuriates Parents and Tests Government. New York Times. https://nyti.ms/2OaiH29 
Hussain, M., \& Dawson, D. (2013). Economic Impact of Food Safety Outbreaks on Food Businesses. Foods. 2(4), 585-589. https://doi.org/10.3390/foods2040585

Jacobs, A. (July 8, 2018). Opposition to Breast-Feeding Resolution by U.S. Stuns World Health Officals. New York Times. https://nyti.ms/2J0WJuV

Bing, C., King, Y., \& Wood, M. (2018, January 23). New Era for Infant Formula in China. China Insight. https://www.chinalawinsight.com/2018/01/articles/corporate/new-era-for-infant-formula-in-china

McDonald, M. (2012, July 23). Carcinogen Found In Chinese Baby Formula. New York Times. https://nyti.ms/2k23m7Z

McFadden, A., Mason, F., Baker, J., Begin, F., Dykes, F., Grummer-Strawn, L., ... Renfrew, M. (2016). Spotlight on infant formula: coordinated global action needed. The Lancet, 387(10017), 413-415. https://doi.org/10.1016/S0140-6736(16)00103-3

Mathews, K., Bernstein, J., \& Buzby, J. (November 2003). Chapter 4: International Trade of Meat/Poultry Products and Food Safety Issues. USDA Electronic Report from the Economic Research Service, Agricultural Economic Report, 828.

Mishen, P. (1996). Strawberry Update: \$16 Million Loss due to Cyclospora. National Food and Agricultural Policy Project, Arizona State University, Tempe, AZ.

Moyer, D., DeVries, J., \& Spink, J. (2017). The economics of a food fraud incident - Case studies and examples including Melamine in Wheat Gluten. Food Control 71, pp 358-364. https://doi.org/10.1016/j.foodcont.2016.07.015

Nelson, A. (2018, February 01). Nestlé under fire for marketing claims on baby milk formulas. The Guardian. https://www.theguardian.com/business/2018/feb/01/nestle-under-fire-for-marketing-claims-on-baby-milk-formulas?CM $\mathrm{P}=$ share_btn_tw

Nicita, A. (March 2008). Avian Influenza and the Poultry Trade. The World Bank Policy Research Working Paper 4551.

Pickelsimer, C., \& Wahl, T. (August 2002). Mad Cow Disease: Implications for World Beef Trade. IMPACT Center Information Series \#96.

Sethi, S. P. (1979). Public Consequences of Private Action: The Marketing of Infant Formula in Less Developed Countries. California Management Review (pre-1986); 21, 35-48.

Siegel, M. (2013, Jan 7). Chinese Saftey Concern Empties Distant Shelves. New York Times. https://nyti.ms/1BIG0FU

Stojkov, K., Noy, I., \& Saglam, Y. (2018). Trade impact of a food scare: Fonterra Contamination Incident. Journal of agricultural and Food Industrial Organization. https://doi.org/10.1515/jafio-2016-0031

Sun, D., Huang, J., \& Yang, J. (2014). Do China's food safety standards affect agricultural trade? The case of dairy products. China Agricultural Economic Review, 6(1), 21-37 https://doi.org/10.1108/CAER-06-2012-0062

UN Comtrade. Retrieved July 2018, from http://comtrade.un.org/data/

Walters, L. (2013, October 04). Dairy Scare Rocks Small NZ Companies. https://www.stuff.co.nz/business/farming/dairy/9278481/Dairy-scare-rocks-small-NZ-companies

WHO. (2013). Country implementation of the International Code of Marketing of Breast-milk Substitutes: status report 2011. Geneva, World Health Organization, 2013 (revised).

Wines, M. (2010, July 9). Tainted Dairy Products Seized in Western China. New York Times. https://nyti.ms/1jE4fPO

Wong, E. (2013, July 25). Chinese Search for Infant Formula Goes Global. New York Times. https://nyti.ms/18OBnhR

The World Bank, World Development Indicators (2018). GDP: NY.GDP.MKTP.CD Retrieved on July 2018, from http://databank.worldbank.org/data/reports.aspx?source=world-development-indicators\#

Xiu, C., \& Klein, K. K. (2010). Melamine in milk products in China: Examining the factors that led to deliberate use of the contaminant. Food Policy, 35, 463-470.

Yardley, J. (2004, May5). Infants in Chinese City Starve on Protein-Short Formula. New York Times. https://nyti.ms/2mU1nCp

\section{Copyrights}

Copyright for this article is retained by the author(s), with first publication rights granted to the journal.

This is an open-access article distributed under the terms and conditions of the Creative Commons Attribution license which permits unrestricted use, distribution, and reproduction in any medium, provided the original work is properly cited. 